Publicação organizada pelo Programa de

Mestrado Profissional Stricto Sensu em

Engenharia Civil da Universidade São Judas

Volume 01 - Edição 01

Janeiro - Dezembro de 2018

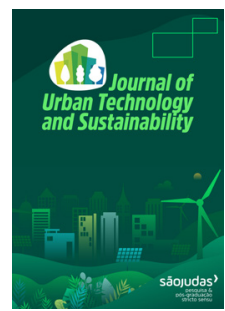

\title{
Effect of specimen shape on the compressive parameters of steel fiber reinforced concrete after exposure to high temperatures
}

\author{
Ramoel Serafinia,b, ${ }^{*}$ Felipe P. Santosa , Ronney R. Agra ${ }^{a, b}$, Albert de la Fuentec, Antonio D. Figueiredo ${ }^{a}$ \\ 'Department of Civil Construction Engineering, Polytechnic School of University of São Paulo | Avenida Professor Almeida Prado, Travessa 2, 83, 05424-970, São Paulo, Brazil. \\ ${ }^{b}$ Institute of Technological Research | Avenida Professor Almeida Prado, 532, 05508-901, São Paulo, Brazil \\ 'Department of Construction Engineering, Polytechnic University of Catalonia | Jordi Girona, 1-3, 08034, Barcelona, Spain
}

\section{Article info}

Received 15 July 2018

Received in revised form 8

September 2018

Accepted 14 September

2018

\section{Keywords}

Steel fiber reinforced

concrete

Elevated temperatures

Compressive strength

Elastic modulus

Shape effect

\begin{abstract}
This study investigated the effect of specimen shape (cylindrical and cubical) on the compressive strength and elastic modulus of steel fiber reinforced concrete after exposure to the temperatures of $150,300,450$, and $600{ }^{\circ} \mathrm{C}$. Results show that the compressive strength and elastic modulus of the composite significantly reduce with the increase in temperature, independent of the specimen shape. Additionally, a significant difference in the compressive strength and elastic modulus conversion factors for cube-cylinder was verified with the increase in temperature. This study contributes to the limited amount of studies regarding the effect of elevated temperatures on steel fiber reinforced concretes and shows that the elevated temperatures may have a significant effect in the conversion factors for cube-cylinder.
\end{abstract}

\section{Efeito da forma do corpo de prova sobre os parámetros mecânicos de concreto reforçado com fibras de aço depois de exposição à temperaturas elevadas}

\section{Informações}

Recebido 15 Julho 2018

Manuscrito revisado recebido

8 Setembro 2018

Aceito 14 Setembro 2018

Palavras-chave

Concreto reforçado com

fibras de aço

Temeraturas elevadas

Resistência à compressão

Módulo de elasticidade

Efeito do formato

\section{Resumo}

Este estudo investigou o efeito do formato do corpo de prova (cilíndrico e cúbico) na resistência à compressão e módulo de elasticidade do concreto reforçado com fibra de aço após exposição às temperaturas de 150, 300, 450 e $600^{\circ} \mathrm{C}$. Os resultados mostram que a resistência à compressão e o módulo de elasticidade do compósito reduzem significativamente com o aumento da temperatura, independente do formato do corpo de prova. Além disso, foi verificada diferença significativa nos fatores de conversão de resistência à compressão e módulo de elasticidade para o cubo-cilíndrico com o aumento da temperatura. Este estudo contribui para a quantidade limitada de estudos sobre o efeito de temperaturas elevadas em concretos reforçados com fibras de aço e mostra que as temperaturas elevadas podem ter um efeito significativo nos fatores de conversão para cubo-cilíndrico.

\section{Efecto de la forma de la probeta sobre los parámetros mecánicos del hormigón reforzado con fibras de acero después de la exposición a temperaturas elevadas}

\section{Información}

Recibido 15 Julio 2018

Manuscrito revisado recibido 8 Septiembre 2018

Aceptado 14 Septiembre 2018

Palabras clave Hormigón reforzado con fibras de acero Temeraturas elevadas Resistência a la compresión Módulo de elasticidad Efecto del formato

\section{Resumen}

Este estudio investigó el efecto de la forma de la probeta (cilíndrica y cúbica) sobre la resistencia a la compresión y el módulo elástico del hormigón reforzado con fibra de acero después de la exposición a temperaturas de $150,300,450$ y $600{ }^{\circ} \mathrm{C}$. Los resultados muestran que la resistencia a la compresión y el módulo elástico del material compuesto se reducen significativamente con el aumento de temperatura, independientemente de la forma de la muestra. Además, se verificó una diferencia significativa en la resistencia a la compresión y en los factores de conversión del módulo elástico para el cilindro-cúbico con el aumento de temperatura. Este estudio contribuye a la cantidad limitada de estudios sobre el efecto de temperaturas elevadas en hormigones reforzados con fibra de acero y muestra que las temperaturas elevadas pueden tener un efecto significativo en los factores de conversión para cubo-cilindro.

\footnotetext{
* Corresponding author at: Department of Civil Construction Engineering, Av. Prof. Almeida Prado, Travessa 2, 83, 05424-970, São Paulo, Brazil. 


\section{Introduction}

The vast majority of applications of steel fiber reinforced concrete (SFRC) as a construction material are associated with infrastructure elements and sanitary systems (FIGUEIREDO, 2012). However, the use of SFRC has expanded beyond these traditional applications in the last years since the publication of design codes and guidelines, especially after the fib Model Code 2010 (FEDERATION INTERNATIONALE DU BETON, 2013). More than that, SFRC has proven to be a competitive material for structural applications (DE LA FUENTE et al., 2011; DI PRISCO; PLIZZARI; VANDEWALLE, 2009; DI PRISCO; TONIOLO, 2000) that enhances toughness, provides a pseudo-ductile behavior to plain concrete, and improves mechanical properties, such as resistance to fatigue and impact. These are some of the aspects responsible for the increase in the demand of SFRC for structural applications as partial or total substitution to conventionally reinforced concrete $(R C)$.

The effect of specimens' shape and size on the compressive strength of concrete has been deeply investigated for almost a century now (GONNERMAN, 1925). The results for all classes of concrete show the influence of specimen's shape and size in the compressive strength of cement-based materials (DEHESTANI; NIKBIN; ASADOLLAHI, 2014; KIM et al., 1999; SIM et al., 2013; SOARES; FLORES-COLEN; DE BRITO, 2015; TOKYAY; ÖZDEMIR, 1997). These results have led to the definition of conversion factors for cube-cylinder strength relations that were implemented in several guidelines worldwide. The main mechanism behind the differences in terms of compressive strength is associated with the slenderness factor $(\mathrm{h} / \mathrm{d}$ ) of each specimen. The geometrical differences and the frictional interaction between the specimen and the platen result in restrained conditions in terms of lateral expansion that generate a rupture cone. This rupture cone induces a higher confinement that generates a triaxial stress state in concrete, which causes an increase in the compressive strength as the $\mathrm{h} / \mathrm{d}$ ratio decreases.

Although a vast amount of research on this subject has been conducted, the studies regarding the effect of specimen size and shape on the compressive properties of cement-based materials after exposure to elevated temperatures remain relatively limited. The study of this relation is particularly necessary since the deleterious effect of temperature on cement-based materials alters the microstructure of the paste, induces an extensive network of cracks and damages the concrete. This is even more important since cylinders and cubes are both commonly used to assess the compressive strength of concrete after temperature exposure, however little is known about the influence of temperature on size effect between the specimens. Therefore, investigations regarding the effect of specimen shape on the mechanical properties of SFRC are relevant and necessary.

In this context, the objective of this study is to evaluate the effect of elevated temperatures on the compressive strength and elastic modulus of SFRC cylindric and cubic specimens. Compressive strength was determined by a series of uniaxial loading tests, while the elastic properties were determined by the displacement transducers for cylindric specimens and by digital image correlation for cubical specimens. Results show that the compressive strength and elastic modulus of the composite significantly reduce with the increase in temperature, independent of the specimen shape. Additionally, a significant difference in the compressive strength and elastic modulus values was found between cylindric and cubical specimens after exposure to elevated temperatures.

\section{Experimental methodology}

\subsection{Materials}

A type I Portland cement (CEM I 52.5R) was used in this study. Table 1 shows the mineralogical composition of cement determined by XRDRietveld refinement. Silica fume type Elkem 920-U $\left(98 \% \mathrm{SiO}_{2}\right)$ was used as pozzolanic material.

River and artificial sand were used as fine aggregates with two coarse granite aggregates $\left(d_{\max }: 19 \mathrm{~mm}\right.$ and $d_{\max }: 9.5 \mathrm{~mm}$ ) to increase particle packing. Table 2 shows the results of $d_{10}, d_{50}, d_{90}$, 
Table 1. Mineralogical composition of cement determined by $\mathrm{XRD/Rietveld}$ refinement.

\begin{tabular}{cc}
\hline Mineral & Quantity (\%) \\
\hline Alite & 55.4 \\
Belite & 14.7 \\
Ferrite & 9.3 \\
Hemihydrate & 6.9 \\
Tricalcium aluminate & 5.4 \\
Calcite & 3.5 \\
Periclase & 1.7 \\
Gypsum & 1.1 \\
Dolomite & 0.9 \\
Portlandite & 0.7 \\
Lime & 0.3 \\
\hline
\end{tabular}

fineness modulus (FM), and specific surface area (SSA) for grained materials. SSA and particle size distribution were determined according to MACIEL et al. (2018).

A superplasticizer specific for precast elements, GRACE ADVA Cast 525, was used to provide consistency to the mix. A cold-drawn hooked-end steel fiber commonly used for structural applications was used as main concrete reinforcement in the composite, Dramix 3D 80/60BG. Anti-spalling polypropylene microfibers, Neomatex FireX, were used to reduce the chances of occurring explosive spalling during fire exposure. Table 3 shows fiber manufacturer data for both fiber types.

\subsection{Composition and preparation of concrete}

The composition of concrete was based on the mix design of the precast segments used in the segmental lining rings for the construction of Subway Line 6 in São Paulo, which is described in Table 4. The steel fiber content adopted in this study was kept at $0.45 \%$ of total volume. The microfiber content was kept at $0.09 \%$ of total volume in order to prevent explosive spalling. Silica fume was used as supplementary cementitious material at a content of $5.5 \%$ of the cement mass, and water to cementitious materials ratio $(\mathrm{w} / \mathrm{cm})$ was kept constant at 0.39. All aggregates were oven dried at $100{ }^{\circ} \mathrm{C}$ for $14 \mathrm{~h}$ before concrete production.

Concrete was prepared in a conventional concrete mixer with capacity of $300 \mathrm{~L}$ in a room at $(25 \pm$ 1) ${ }^{\circ} \mathrm{C}$. First, cement, silica fume, coarse aggregates, and a third of total water and superplasticizer were pre-mixed and then added to the mixer and homogenized for $3 \mathrm{~min}$. Then fine aggregates and a third of water mixed with superplasticizer were added and homogenized for the same time period. At last, the remaining one third of water and superplasticizer were added and macro- and microsynthetic fibers were slowly added during 3 min of mixture. The composition was, then, mixed for 6 min. The SFRC presented a specific weight equal to $(2430 \pm 52) \mathrm{kg} / \mathrm{m}^{3}$ and a slump value of $(4 \pm 1) \mathrm{cm}$ (average obtained from three determinations).

Concrete was cast in steel molds in one layer consolidated in a vibrating table with a frequency of $60 \mathrm{~Hz}$ for $60 \mathrm{~s}$. A total of 30 cylindric specimens with diameter of $100 \mathrm{~mm}$ and height of $200 \mathrm{~mm}$ (h/ $d=2$ ) and 10 prismatic specimens with dimensions of $100 \times 100 \times 350 \mathrm{~mm}$ were produced. Prismatic specimens were, then, cut in cubes of $100 \times 100 \mathrm{~mm}$ and for the compressive strength test. A total of 30 cubic specimens were produced following this procedure, resulting in 6 cubic specimens for each target temperature. All specimens were cured in a saturated room for $72 \mathrm{~h}$, and then stored at room temperature until the age of 28 days to better simulate in situ humidity and curing conditions.

Table 2. Results of $d_{10}, d_{50}, d_{90}$, fineness modulus, and specific surface area for grained materials.

\begin{tabular}{|c|c|c|c|c|c|}
\hline Materials & $d_{10}(\mu m)$ & $d_{50}(\mu m)$ & $d_{90}(\mu m)$ & FM & SSA $\left(\mathrm{m}^{2} / \mathrm{g}\right)$ \\
\hline Cement CEM I 52.5R & 2.34 & 15.71 & 41.49 & - & 1.37 \\
\hline Silica fume & 1.93 & 8.85 & 19.50 & - & 16.00 \\
\hline River sand & 177.79 & 341.13 & 705.66 & 1.15 & - \\
\hline Artificial sand & 69.03 & 2580 & 4230 & 3.55 & - \\
\hline Aggregate dmax:9.5mm & 2390 & 5540 & 8720 & 5.45 & - \\
\hline Aggregate dmax:19mm & 9210 & 14390 & 18280 & 6.80 & - \\
\hline Aggregate dmax:19mm & 9210 & 14390 & 18280 & 6.80 & - \\
\hline
\end{tabular}


Table 3. Fiber manufacturer data for both fiber types

\begin{tabular}{ccc}
\hline Characteristics & $\begin{array}{c}\text { Hooked-end } \\
\text { steel fiber }\end{array}$ & $\begin{array}{c}\text { Micro-synthetic } \\
\text { fiber }\end{array}$ \\
\hline Length $(\mathrm{mm})$ & 60 & 12 \\
Diameter $(\mathrm{mm})$ & 0.75 & 0.03 \\
Aspect ratio $(\mathrm{l} / \mathrm{d})$ & 80 & Not provided \\
Specific weight $(\mathrm{kg} /$ & 7850 & 910 \\
$\left.\mathrm{~m}^{3}\right)$ & Not provided & 147 \\
$\begin{array}{c}\text { Specific surface area } \\
\left(\mathrm{m}^{2} / \mathrm{kg}\right)\end{array}$ & Not provided \\
$\begin{array}{c}\text { Melting point }\left({ }^{\circ} \mathrm{C}\right) \\
\text { Tensile strength }(\mathrm{MPa})\end{array}$ & 1225 & Not provided \\
Young modulus $(\mathrm{GPa})$ & 210 & Not provided \\
\hline
\end{tabular}

\subsection{Electric oven heating procedure}

An industrial INFORGEL GENGA electric oven, model GCR.SP, with maximum temperature of 1000 ${ }^{\circ} \mathrm{C}$ was used to heat cylindric specimens. Specimens were heated for the target temperatures of 150 , 300,450 , and $600{ }^{\circ} \mathrm{C}$ at a heating rate of (12 \pm 2) ${ }^{\circ} \mathrm{C} / \mathrm{min}$. This considerable variability in heating rate is a characteristic of electric ovens with a fix power capacity, since heating rate decreases as temperature increases. The time period at target temperature was of $2 \mathrm{~h}$ for all evaluated temperatures, which was determined based on the duration of the hydrocarbon fire curve. After the temperature exposure was over, the chamber was kept closed and cooling until the room temperature was achieved during $24 \mathrm{~h}$. The cooling rate was not controlled.

\subsection{Compressive strength tests}

Cylindric and cubic specimens were evaluated

Table 4. Dosage of materials to produce one cubic meter of steel fiber reinforced concrete.

\begin{tabular}{cc}
\hline Materials & Dosage $\left(\mathbf{k g} / \mathbf{m}^{\mathbf{3}}\right)$ \\
\hline Portland cement & 400 \\
Silica fume & 22 \\
Water & 165 \\
Siliceous river sand & 403 \\
Artificial granite sand & 269 \\
Coarse granite aggregate - $\mathrm{d}_{\text {max }}: 19 \mathrm{~mm}$ & 770 \\
Coarse granite aggregate - $\mathrm{d}_{\text {max }}: 9.5 \mathrm{~mm}$ & 330 \\
Superplasticizer & 3 \\
Micro-synthetic fiber - antispalling & 0.80 \\
Hooked-end steel fiber & 35 \\
\hline
\end{tabular}

regarding the compressive strength and elastic modulus. Tests were conducted on a Shimadzu Universal Testing Machine, model UH-F2000kN, with a computer-controlled hydraulic servo system, and maximum load capacity of 2000 kN. The test was load-controlled at a rate of $0.5 \mathrm{MPa} / \mathrm{s}$ and a total of 60 specimens were tested, being 30 cylinders and 30 cubes ( 6 specimens for each target temperature). All results obtained from the mechanical characterization were statistically analyzed through analysis of variances (ANOVA) and Tukey tests.

\subsection{Elastic modulus}

\subsubsection{Cylindric specimens}

Figure 1 shows the test setup used to assess the elastic properties of the cylindric specimens. The SFRC axial strain was determined by the average readings of two displacement transducers attached around the specimen. The elastic modulus was obtained on the range of the stress-strain curves

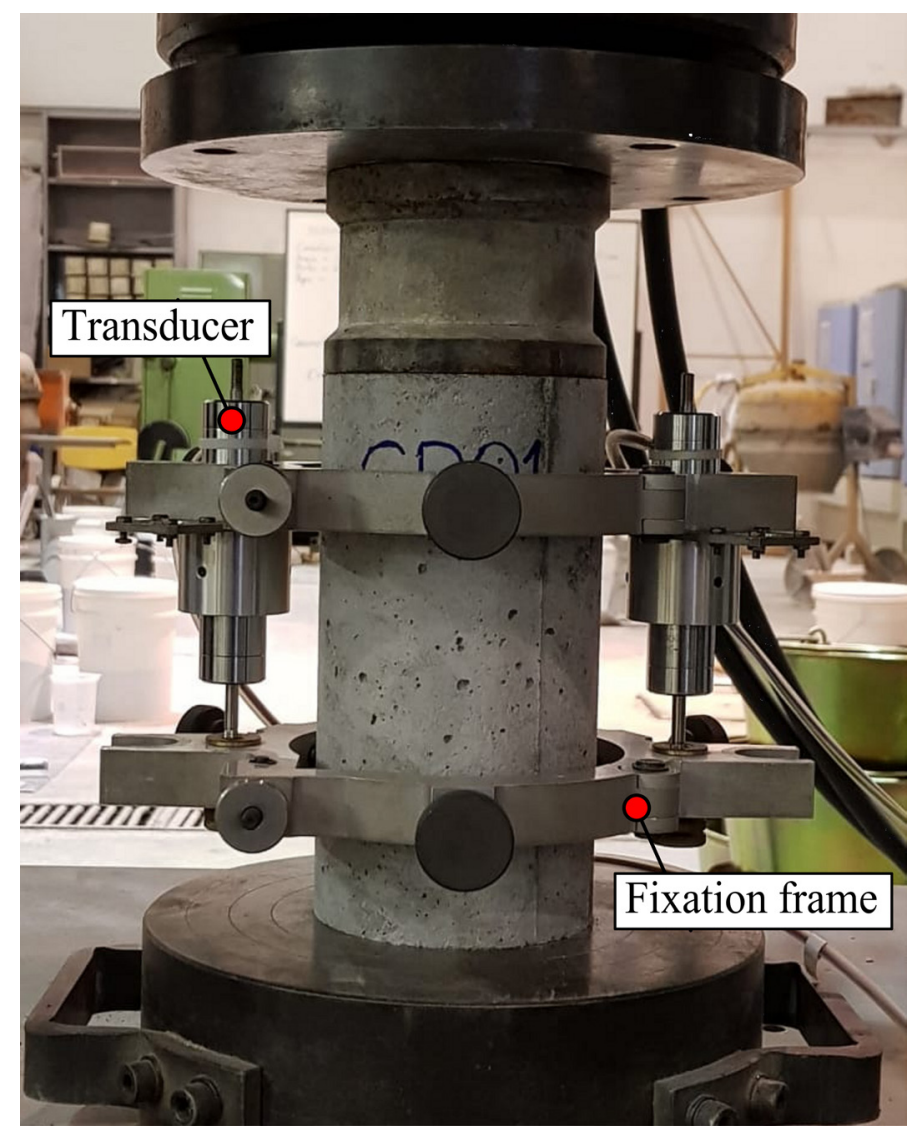

Fig. 1. The test setup used to assess the elastic properties of the cylindric specimens. 
located between 0.5 MPa and 0.3fc. Taking into consideration that specimens were severely affected by temperature, only one loading cycle was performed in order to determine the elastic modulus.

\subsubsection{Cubic specimens}

Figure 2 shows the preparation of cubic specimens and the data acquisition setup for the image analysis conducted in this study. The elastic modulus of cubic specimens was evaluated through the use of digital image correlation technique. For image analysis, a single face of each cubic specimen was completely covered with three white paint layers (Fig. 2a) and one last black dot pattern layer. This aims to generate black and white contrast allowing further software analysis to precisely measure displacement in several points of the specimen (Fig. 2b). Images were acquired using a Canon Rebel $\mathrm{T} 4 \mathrm{i}$ digital camera with an EFS 18-55mm optical lens at a rate of 1 picture per second and the light incidence was increased over the painted surface by the use of LEDs. The image acquisition setup for the image analysis can be seen at Figure 2c.

After acquiring the test data, images were analyzed by VIC-2D digital image interactive software. This software uses a computer system to compare a sequence of images, tracing the movement of each point at the cubic specimen evaluated and correlating each image to each value of time ("t" and " $t+d t$ "). This methodology is based on a series of algorithms to compute the data (SCHREIER; ORTEU; SUTTON, 2009) from which it is possible to obtain strain values for each specimen evaluated and, thus, calculate the elastic modulus. The image analysis was conducted avoiding the outer border of the specimen in order to minimize error and variation. A resolution of $\sim 4$ megapixels was obtained and the processing time for each specimen varied from 60 to 90 minutes depending on the duration of the test. Modulus of elasticity was calculated considering the secant line between $5 \%$ and $30 \%$ of the maximum compressive strength value (fc) to avoid initial accommodation of specimen and possible instability close to rupture.

\section{Results and discussion}

\subsection{Compressive strength}

Figure 3 shows the stress-strain curves as a function of temperature for the cylindric and cubic specimens. The average compressive strength results for cylindric and cubical specimens as a function of temperature can be found in Table 5. Results show that the compressive strength of SFRC significantly reduced with temperature
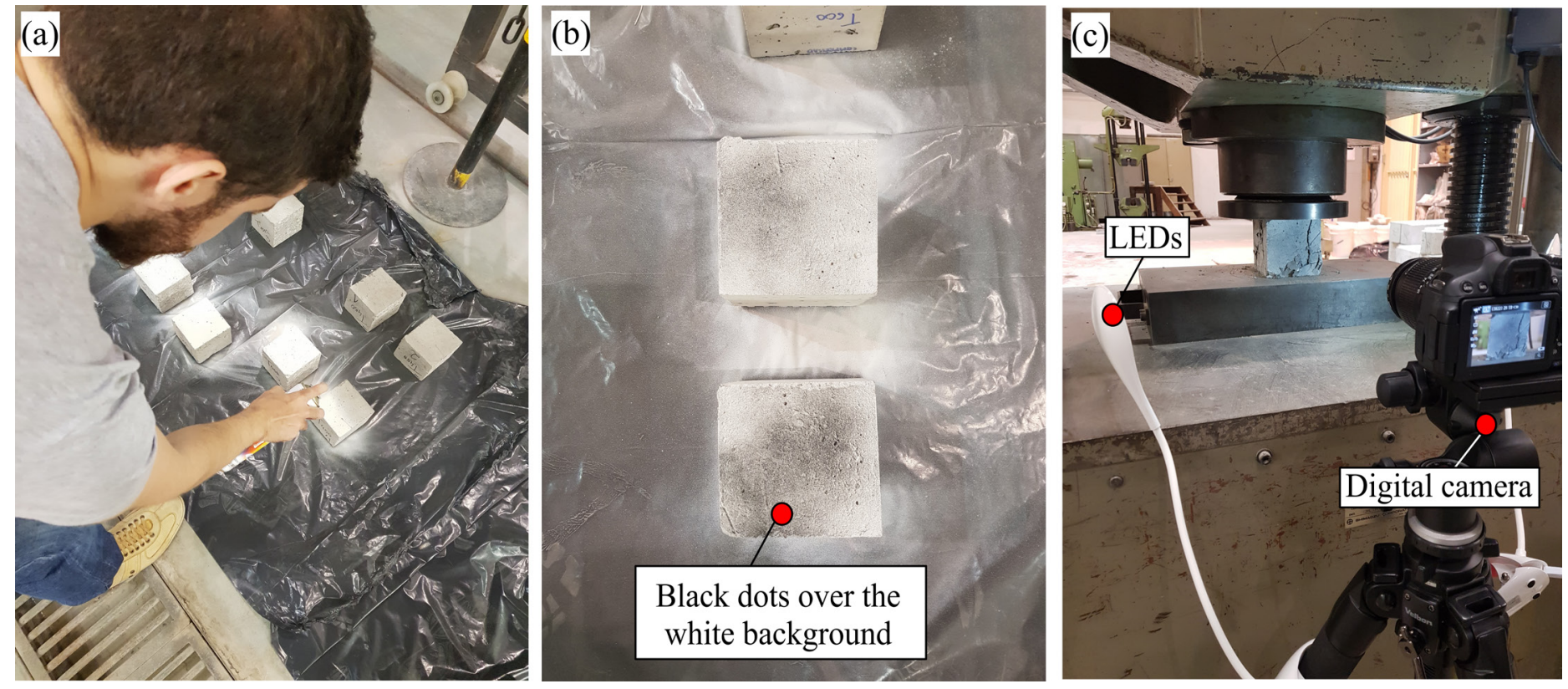

Fig. 2. (a) preparation of cubic specimens, (b) dots for black and white contrast, and (c) the image acquisition setup. 
increase. This may be attributed to the mismatch between aggregates and paste in terms of thermal expansion, which results in the formation of microcracks in the interfacial transition zone, as well as to the severe dehydration of hydrated products (BAŽANT; KAPLAN, 1996).

For cylindric specimens, the compressive strength values after temperature exposure of 150, 300, 450, and $600{ }^{\circ} \mathrm{C}$ were, respectively, 2.3\%, 7.5\%, 23.7\%, and $54.7 \%$ lower than the value reached at room temperature. Additionally, no significant difference was found in terms of compressive strength for results up to $150{ }^{\circ} \mathrm{C}$, which is in line with the classical literature (BAŽANT; KAPLAN, 1996) and also with results found in literature (CHEN et al., 2014; MÜLLER; NOVÁK; POON; SHUI; LAM, 2004; ZHENG; LI; WANG, 2012). This non-significance is directly associated with the relatively small amount of microstructural and physical changes in this initial temperature range (BAŽANT; KAPLAN, 1996; SCRIVENER; SNELLINGS; LOTHENBACH, 2017), which results in minor effects in compressive strength.

For cubic specimens, the compressive strength values after temperature exposure of 150, 300, 450 , and $600{ }^{\circ} \mathrm{C}$ were, respectively, $0.2 \%, 2.4 \%$, $18.9 \%$, and $45.8 \%$ lower than the value reached at room temperature. The changes in compressive strength values up to temperatures of $300{ }^{\circ} \mathrm{C}$ were not significant when compared to room temperature results. Even with that, a significative reduction of $18.9 \%$ and $45.8 \%$ was verified for the respective target temperatures of 450 and $600{ }^{\circ} \mathrm{C}$, which are significantly lower than the reductions obtained by the cylindric specimens at the same target temperature. This denotes that the cubical specimens may not be capable of assessing the mechanical changes in terms of compressive strength for temperatures lower than $300{ }^{\circ} \mathrm{C}$. The non-significance of results up to $300^{\circ} \mathrm{C}$ for cubical specimens may be a side effect of the higher confinement and the generated triaxial stress state in the composite, which arises from the reduced h/d ratio.

It is important to state that the definition of the mechanical properties in the temperature range
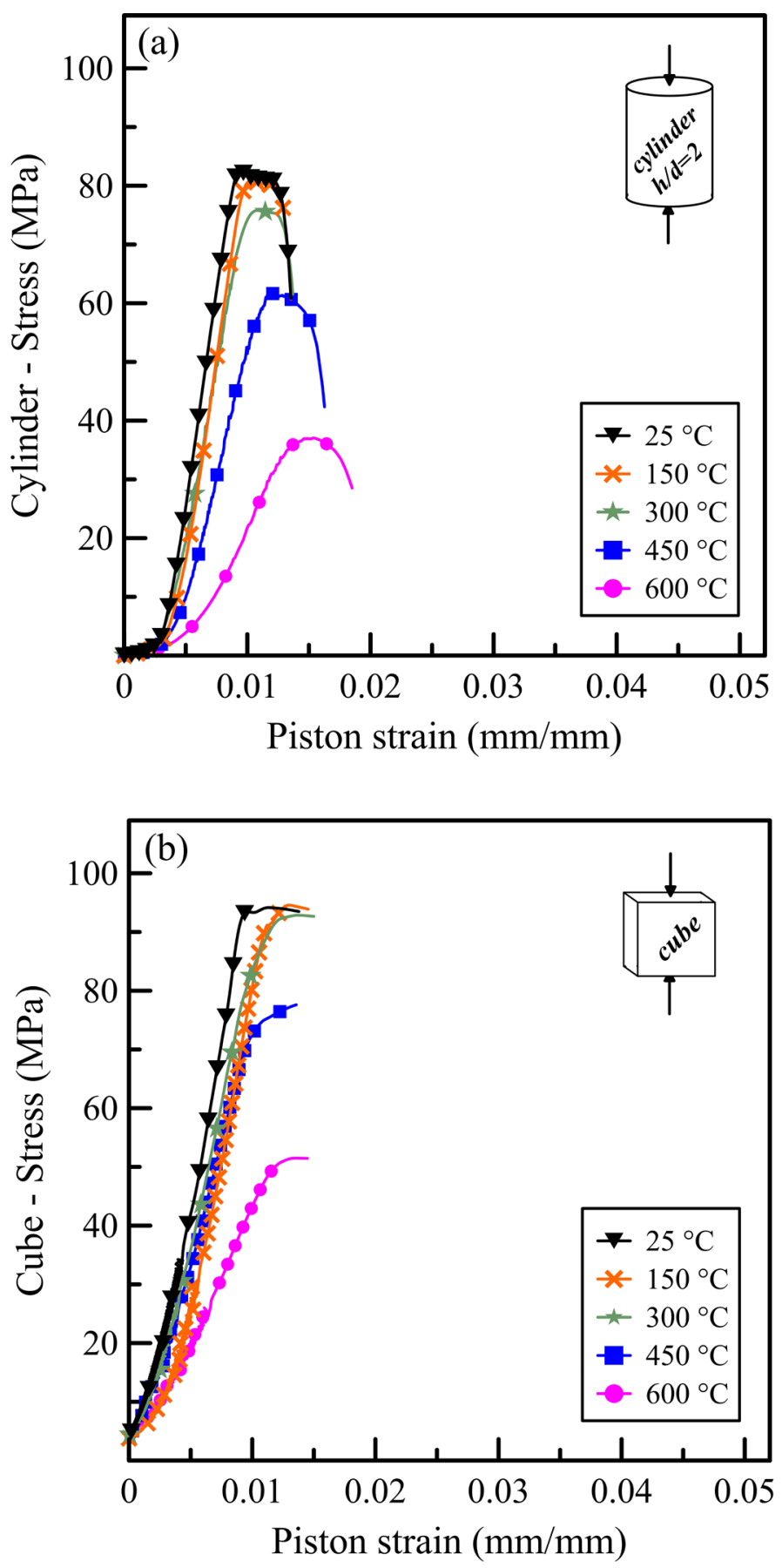

Fig. 3. Stress-strain curves as a function of temperature for the (a) cylindric and (b) cubic specimens.

of 25 to $300{ }^{\circ} \mathrm{C}$ is a key parameter to be used in numerical simulation models for the post-fire assessment of structures. This is especially true since in a real fire event the internal temperatures may range from $\sim 100$ to about $\sim 700{ }^{\circ} \mathrm{C}$ inside the concrete, and the mechanical properties in the temperature range of 25 to $300{ }^{\circ} \mathrm{C}$ represent a considerable portion of the cross-sectional area of elements affected by fire. Therefore, the use of cubical specimens limits the sensibility of changes in terms of compressive strength when compared to cylindric specimens for temperatures below 
Table 5. Compressive strength values as a function of temperature and specimen shape.

\begin{tabular}{ccc}
\hline \multirow{2}{*}{$\begin{array}{c}\text { Temperature } \\
\left({ }^{\circ} \mathbf{C}\right)\end{array}$} & \multicolumn{2}{c}{ Compressive strength (MPa) } \\
\cline { 2 - 3 } & Cylindric specimens & Cubical specimens \\
\hline 25 & $82.6( \pm 1.4)$ & $94.9( \pm 0.7)$ \\
150 & $80.2( \pm 2.2)$ & $94.7( \pm 0.4)$ \\
300 & $76.4( \pm 2.3)$ & $92.6( \pm 1.6)$ \\
450 & $63.0( \pm 0.6)$ & $76.9( \pm 3.8)$ \\
600 & $37.5( \pm 1.1)$ & $51.4( \pm 2.4)$ \\
\hline
\end{tabular}

$300{ }^{\circ} \mathrm{C}$. This may culminate in limitations when extrapolating the mesoscale results of SFRC to the level of a real SFRC structure, which results in models that may be further from the safe side. Another relevant aspect is that the physical-mechanical properties of the steel fibers are affected by the increase in temperature.

Figure 4 shows the effect of temperature on the compressive strength of cubic and cylindric specimens and the ratio between them. It is possible to observe that the compressive strength of cubical specimens is greater than the compressive strength of cylindric specimens for all temperatures evaluated (Fig. 4a). The compressive strength of cubic specimens is $14.7 \%$ greater than the compressive strength of cylindric specimens at room temperature, which agrees well with literature results in terms of conversion factors between highstrength concrete cubes and cylinders (FEDERATION INTERNATIONALE DU BETON, 2013; YI; YANG; CHOI, 2006).

Additionally, the compressive strength of cubic specimens exposed to temperatures of 150,300 , 450 , and $600{ }^{\circ} \mathrm{C}$ were $18.3 \%, 21.1 \%, 22.0 \%$, and $37.4 \%$ greater than those obtained by cylindric specimens. This shows that the conversion factors for cube-cylinder relations increase with the increase in temperature, especially for the temperature of $600{ }^{\circ} \mathrm{C}$. These changes seem to follow a linear relationship (see Fig. 4b) and may be directly associated with the higher confinement generated by the rupture cone formation in cubic specimens paired with the effects of elevated temperature on the composite.

\subsection{Elastic properties}

Figure 5 shows the effect of temperature on the elastic modulus of cubic and cylindric specimens and the ratio between them. Table 6 shows the elastic modulus values as a function of temperature and specimen shape. For cylindric specimens, the elastic modulus values after temperature exposure of $150,300,450$, and $600{ }^{\circ} \mathrm{C}$ were, respectively, $24.7 \%, 74.1 \%, 93.8 \%$, and $97.6 \%$ lower than the value reached at room temperature. For cubic
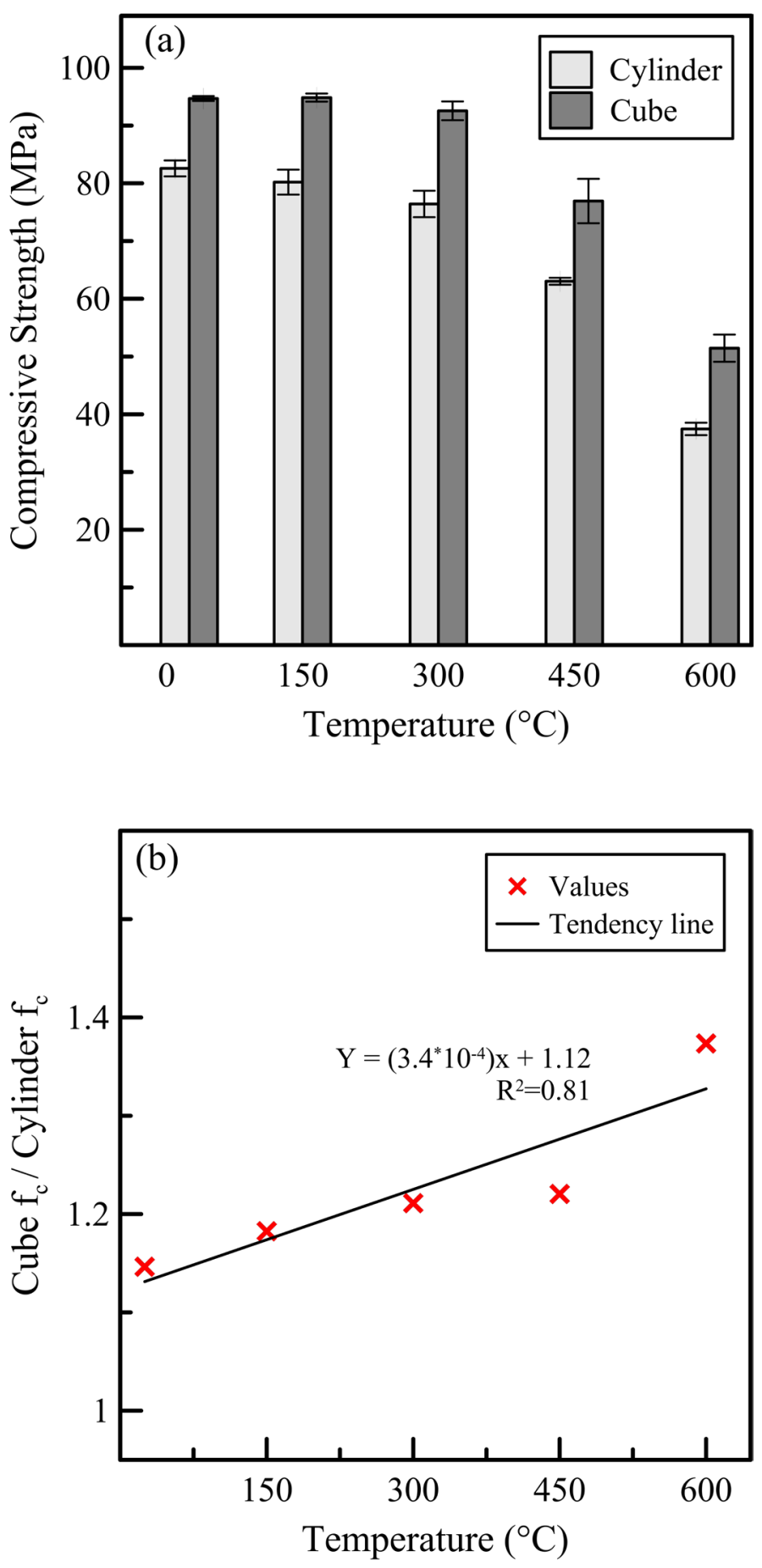

Fig. 4. The effect of temperature on (a) the compressive strength of cubic and cylindric specimens and (b) the ratio between them. 
specimens, the reductions in terms of elastic modulus were of $23.9 \%, 52.5 \%, 70.1 \%$, and $90.1 \%$ for the temperatures of $150,300,450$, and $600^{\circ} \mathrm{C}$, respectively, when compared to room temperature results.

The elastic modulus is a property that is intrinsically bound to the concrete mix, in terms of the percentage of aggregates, paste, fibers, and porosity, which are the same among specimens of different shapes. Therefore, the results show that the values of elastic modulus are comparable for both cubical and cylindric specimens in room
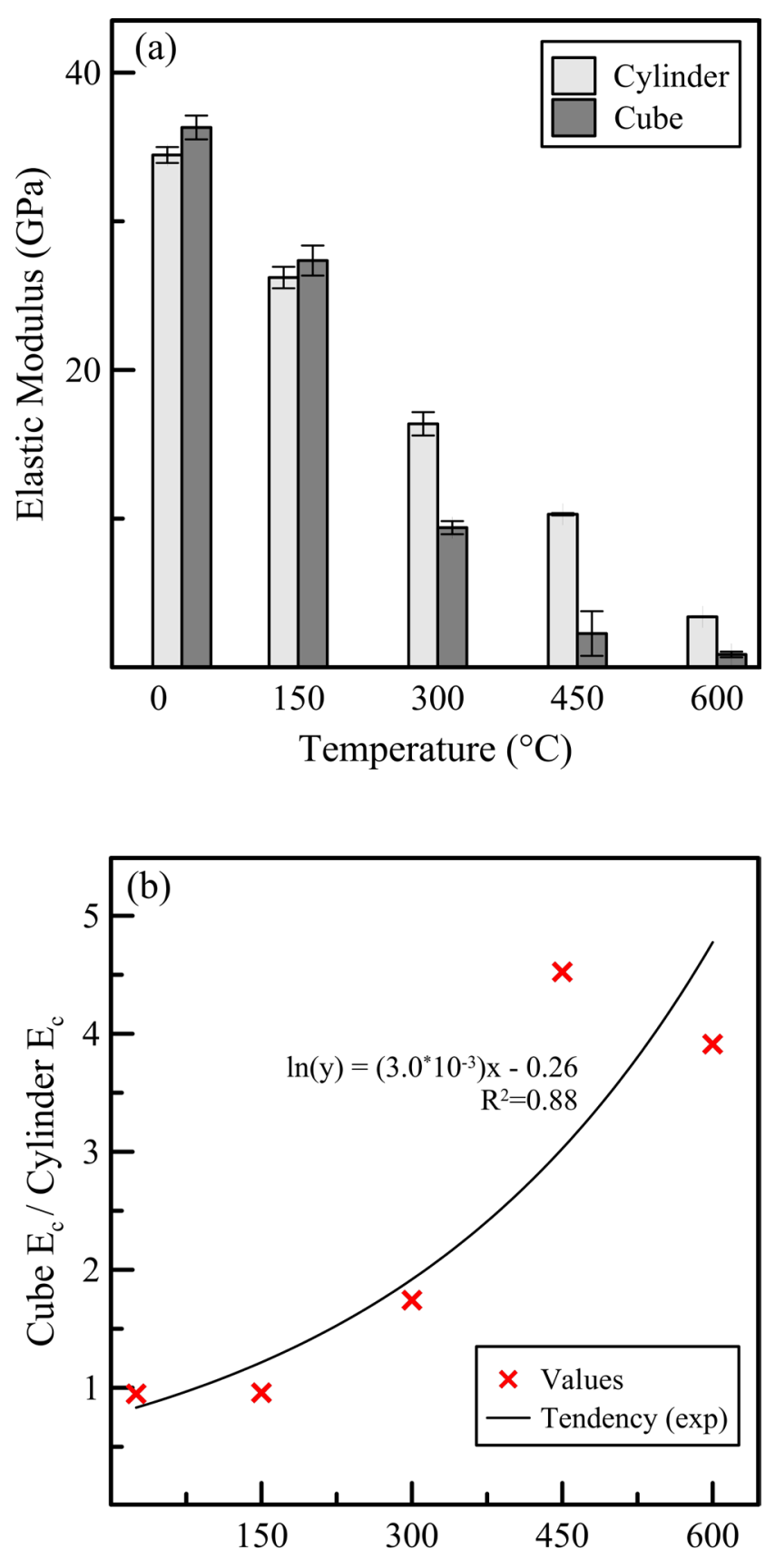

Temperature $\left({ }^{\circ} \mathrm{C}\right)$

Fig. 5. The effect of temperature on (a) the elastic modulus of cylindric and cubic specimens and (b) the ratio between them. temperature. As temperature increases, the elastic modulus of cylindric specimens decrease more rapidly than the elastic modulus of cubic specimens (see Fig. 5a) and the stiffness difference between cubic and cylindric specimens seems to exponentially increase with temperature (see Fig. $5 b)$. This difference is mainly associated with the restrained conditions in terms of lateral expansion due to the high platen friction acting on the cubic specimen, which results in reduced vertical deformation.

Results found in literature show that an elastic modulus difference between cubic and cylindric specimens may reach up to $8 \%$ for room temperature results (WU et al., 2018) due to the restrained conditions of the specimen. This restrained condition effect, however, seems to be even more significantly after exposure to elevated temperatures, which may be a result of the coarsening of the pore structure, increase in terms of cement paste porosity (GALLUCCl; ZHANG; SCRIVENER, 2013; VYDRA et al., 2001), and the triaxial stress state that is generated in cubic specimens. In this sense, the porosity changes affect more significantly the vertical deformation of cylindric specimens than the cubical ones due to the higher h/d ratio. Therefore, the effect of temperature on the elastic modulus conversion factors for cubecylinder relations may be a concerning factor when determining the elastic properties of the material and need to be deeply investigated in the future, as well as the effect of the methodology employed in the results.

Despite the effect of specimen shape on results, it is clear that the elastic modulus drastically reduces with increase in temperature. This reduction may

Table 6. Elastic modulus values as a function of temperature and specimen shape.

\begin{tabular}{ccc}
\hline \multirow{2}{*}{$\begin{array}{c}\text { Temperature } \\
\left({ }^{\circ} \mathbf{C}\right)\end{array}$} & \multicolumn{2}{c}{ Elastic Modulus (GPa) } \\
\cline { 2 - 3 } & Cylindric specimens & Cubical specimens \\
\hline 25 & $36.3( \pm 0.5)$ & $34.5( \pm 0.8)$ \\
150 & $27.4( \pm 0.7)$ & $26.2( \pm 1.0)$ \\
300 & $9.4( \pm 0.8)$ & $16.4( \pm 0.4)$ \\
450 & $2.28( \pm 0.08)$ & $10.3( \pm 1.5)$ \\
600 & $0.87( \pm 0.03)$ & $3.4( \pm 0.2)$ \\
\hline
\end{tabular}


be attributed to the severe dehydration of hydrated products with temperature increase, since this dehydration process results in the coarsening of the cement paste pore structure, which greatly affects the elastic properties of the composite (BAŽANT; KAPLAN, 1996. The reduction values obtained for cylindric specimens are in line with studies found in literature (LAU; ANSON, 2006; RAMBO et al., 2018; ZHENG; LI; WANG, 2012) for the same class of concrete and tested in comparable conditions, while the results obtained for cubical specimens show smaller reduction values.

\section{Conclusions}

The following conclusions may be drawn from the present study:

- For cylindric specimens, the compressive strength values after temperature exposure of 150, 300, 450, and $600{ }^{\circ} \mathrm{C}$ were, respectively, $2.3 \%, 7.5 \%, 23.7 \%$, and $54.7 \%$ lower than the value reached at room temperature. Additionally, no significant difference was found in terms of compressive strength for results up to $150{ }^{\circ} \mathrm{C}$, which was attributed to the small amount of microstructural and physical changes in this initial temperature range.

- For cubic specimens, the compressive strength values after temperature exposure of $150,300,450$, and $600{ }^{\circ} \mathrm{C}$ were, respectively, $0.2 \%, 2.4 \%, 18.9 \%$, and $45.8 \%$ lower than the value reached at room temperature. The changes in compressive strength values up to temperatures of $300{ }^{\circ} \mathrm{C}$ were not significant when compared to room temperature results. This may denote that the cubical specimens may not be capable of assessing the mechanical changes in terms of compressive strength for temperatures lower than $300^{\circ} \mathrm{C}$.

- The compressive strength of cubic specimens was $14.7 \%$ greater than the compressive strength of cylindric specimens at room temperature, which agrees well with literature results. Additionally, the compressive strength of cubic specimens exposed to temperatures of $150,300,450$, and $600^{\circ} \mathrm{C}$ were $18.3 \%, 21.1 \%, 22.0 \%$, and $37.4 \%$ greater than those obtained by cylindric specimens. This shows that the conversion factors for cube-cylinder relations increase with the increase in temperature.

- For cylindric specimens, the elastic modulus values after temperature exposure of 150, 300, 450, and $600{ }^{\circ} \mathrm{C}$ were, respectively, $24.7 \%, 74.1 \%, 93.8 \%$, and $97.6 \%$ lower than the value reached at room temperature. For cubic specimens, the reductions in terms of elastic modulus were of $23.9 \%, 52.5 \%$, $70.1 \%$, and $90.1 \%$ for the temperatures of 150,300 , 450 , and $600{ }^{\circ} \mathrm{C}$, respectively, when compared to room temperature results.

- The values of elastic modulus are comparable for both cubical and cylindric specimens in room temperature. As temperature increases, the elastic modulus of cylindric specimens decrease more rapidly than the elastic modulus of cubic specimens and the stiffness difference between cubic and cylindric specimens seems to exponentially increase with temperature.

\section{Acknowledgements}

The authors would like to thank the Institute for Technological Research (IPT) and its foundation (FIPT) for their financial and institutional support though the New Talents Program N.01/2017 and N.01/2018.

\section{References}

BAŽANT, Z. P.; KAPLAN, M. F. Concrete at high temperatures: material properties and mathematical models. London: Longman, 1996.

CHEN, G. M.; HE, Y. H.; YANG, H.; CHEN, J. F.; GUO, Y. C. Compressive behavior of steel fiber reinforced recycled aggregate concrete after exposure to elevated temperatures. Construction and Building Materials, v. 71, p. 1-15, 2014.

DE LA FUENTE, A.; AGUAdO, A.; MOLINS, C.; ARMENGOU, J.. Innovations on components and testing for precast panels to be used in reinforced earth retaining walls. Construction and Building Materials, v. 25, n. 5, p. 2198-2205, 2011. 
DEHESTANI, M.; NIKBIN, I. M.; ASADOLLAHI, S. Effects of specimen shape and size on the compressive strength of self-consolidating concrete (SCC). Construction and Building Materials, v. 66, p. 685-691, 2014.

DI PRISCO, M.; PLIZZARI, G.; VANDEWALLE, L. Fibre reinforced concrete: new design perspectives. Materials and Structures, v. 42, n. 9, p. 1261-1281, 2009.

DI PRISCO, M.; TONIOLO, G.. Structural applications of steel fibre reinforced concrete. In: PROCEEDINGS OF INTERNATIONAL WORKSHOP 2000, Milan (Italy). Anais [...]. Milan (Italy): CTE Publ., 2000. Disponível em: http://hdl.handle.net/11311/248435.

FEDERATION INTERNATIONALE DU BETON. Model Code for Concrete Structures 2010. In: Germany: Ernst \& Sohn, 2013. p. 434.

FIGUEIREDO, A. D. Concreto reforçado com fibras. 2012. Tese (livre-docência) - Universidade de São Paulo, São Paulo, 2012.

GALLUCCI, E.; ZHANG, X.; SCRIVENER, K. L. Effect of temperature on the microstructure of calcium silicate hydrate $(\mathrm{C}-\mathrm{S}-\mathrm{H})$. Cement and Concrete Research, v. 53, p. 185-195, 2013. DOI: 10.1016/j. cemconres.2013.06.008.

GONNERMAN, H. F. Effect of size and shape of test specimen on compressive strength of concrete. Chicago: Structural Materials Research Laboratory, 1925.

KIM, J. K.; YI, S. T.; PARK, C. K.; EO, S. H. Size effect on compressive strength of plain and spirally reinforced concrete cylinders. ACI Structural Journal, v. 96, n. 1, p. 88-94, 1999.

LAU, A.; ANSON, M. Effect of high temperatures on high performance steel fibre reinforced concrete. Cement and Concrete Research, v. 36, n. 9, p. 1698-1707, 2006.

MACIEL, M. H.; BERNARDO, H. M.; SOARES, G. S.;
ROMANO, R. C. O.; CINCOTTO, M. A.; PILEGGI, R. G. Efeito da variação do consumo de cimento em argamassas de revestimento produzidas com base nos conceitos de mobilidade e empacotamento de partículas. Ambiente Construído, v. 18, n. 1, p. 245-259, 2018.

POON, C. S.; SHUI, Z. H.; LAM, L. Compressive behavior of fiber reinforced high-performance concrete subjected to elevated temperatures. Cement and Concrete Research, v. 34, n. 12, p. 2215-2222, 2004.

RAMBO, D. A. S.; BLANCO, A.; FIGUEIREDO, A. D.; SANTOS, E. R. F.; TOLEDO, R. D.; GOMES, O. F. M.. Study of temperature effect on macro-synthetic fiber reinforced concretes by means of Barcelona tests: An approach focused on tunnels assessment. Construction and Building Materials, v. 158, p. 443-453, 2018.

SCHREIER, H.; ORTEU, J.; SUTTON, M. A. Image Correlation for Shape, Motion and Deformation Measurements. Boston: Springer US, 2009.

SCRIVENER, K.; SNELLINGS, R.; LOTHENBACH, B. A Practical Guide to Microstructural Analysis of Cementitious Materials. London: CRC Press, 2017.

SIM, J.; YANG, K.; KIM, H.; CHOI, B. Size and shape effects on compressive strength of lightweight concrete. Construction and Building Materials, v. 38, p. 854-864, 2013.

SOARES, A.; FLORES-COLEN, I.; DE BRITO, J. Influence of slenderness on the compressive strength evaluation of cores of renders. Materials and Structures, v. 48, n. 5, p. 1449-1460, 2015.

TOKYAY, M.; ÖZDEMIR, M. Specimen shape and size effect on the compressive strength of higher strength concrete. Cement and Concrete Research, v. 27, n. 8, p. 1281-1289, 1997.

VYDRA, V.; VODÁK, F.; KAPIČKOVÁ, O.; HOŠKOVÁ, Š. Effect of temperature on porosity of concrete for nuclear-safety structures. Cement and Concrete 
Research, v. 31, n. 7, p. 1023-1026, 2001.

WU, Bo; YU, Yong; CHEN, Zongping; ZHAO, Xiaolong. Shape effect on compressive mechanical properties of compound concrete containing demolished concrete lumps. Construction and Building Materials, v. 187, p. 50-64, 2018.

YI, S.; YANG, E.; CHOI, J. Effect of specimen sizes, specimen shapes, and placement directions on compressive strength of concrete. Nuclear Engineering and Design, v. 236, n. 2, p. 115-127, 2006.

ZHENG, W.; LI, H.; WANG, Y. Compressive stressstrain relationship of steel fiber-reinforced reactive powder concrete after exposure to elevated temperatures. Construction and Building

Materials, v. 35, p. 931-940, 2012. 